\title{
Pemberdayaan Karang Taruna dalam Pembuatan E-Katalog Kampung Tematik Kota Semarang
}

\author{
Muhamad Hasan Basori $^{1 *}$, Choirul Ulil Albab ${ }^{1,}$ Naiza Rosalia $^{1}$, Fibriyani Nur Aliya ${ }^{1}$ \\ ${ }^{1}$ Ilmu Komunikasi, Fakultas Ilmu Komputer, Universitas Dian Nuswantoro, \\ Jl. Imam Bonjol No 205-207 Semarang \\ Email Penulis Korespodensi: hasansbasori@gmail.com
}

\begin{abstract}
Kampung Tematik of Semarang City is a government program to develop the society's economy, through naming the kampung based on their potential. This makes Kampung Tematik seen as a product, thus forcing promotional activities. On the other hand, the promotion for Kampung Tematik has no good enough promotion. Digitalization demands a transformation of promotion tools, one of which is the catalog. The young generation is the most adaptive generation to face digitalization. Karang Taruna as the younger generation is considered to be the main power of the city's success. Based on this, this community service seeks to motivate Youth Organization to contribute significantly to supporting the Kampung Tematik program in Semarang City. It begins with the need for digital promotion for Kampung Tematik, this activity aims to improve knowledge and the ability to make ECatalogues. The online service method used to teach graphic design and copywriting materials both theoretical and practical for E-Catalogue. Based on the results of the pre-test and post-test, it is known that the average increase in knowledge is $23 \%$, understanding is $28,5 \%$, and implementation ability is 41,5\%. Based on these results, it can be seen that this empowerment activity has benefits.
\end{abstract}

\section{Keywords: Grapic Design, Copywriting, E-Catalogue, Kampung Tematik}

\begin{abstract}
Abstrak
Kampung Tematik Kota Semarang merupakan program pemerintah untuk memajukan perekonomian masyarakat, melalui penamaan kampung berdasar potensi yang dimiliki. Hal ini membuat kampung tematik dipandang sebagai sebuah produk, sehingga memaksa dilakukannya kegiatan promosi. Di sisi lain promosi untuk kampung tematik dinilai sangat kurang. Kemajuan teknologi digital menuntut transformasi alat promosi, salah satunya promosi melalui E-Katalog. Generasi muda dinilai sebagai generasi yang paling adaptif menghadapi digitalisasi. Karang Taruna sebagai generasi muda dianggap sebagai ujung tombak keberhasilan kota. Berdasar hal tersebut, pengabdian masyarakat ini berupaya menggerakkan Karang Taruna untuk berkontribusi secara nyata dalam mendukung program Kampung Tematik di Kota Semarang. Berangkat dari kebutuhan promosi digital untuk Kampung Tematik, pengabdian ini bertujuan memberikan pengetahuan dan kemampuan membuat EKatalog. Metode pengabdian, dilakukan secara daring, kegiatan diisi dengan memberikan materi desain grafis dan copywriting baik teoritis maupun praktis dan implementatif untuk E-Katalog. Berdasarkan hasil pre test dan post test diketahui rata-rata peningkatan pengetahuan sebesar 23\%, pemahaman sebesar 28,5\%, dan kemampuan implementasi sebesar 41,5\%. Berdasar hasil tersebut, dapat dilihat bahwa kegiatan pemberdayaan ini memiliki kebermanfaatan baik pada tataran kognisi maupun praktis untuk anggota Karang Taruna Kota Semarang.
\end{abstract}

Kata kunci: Desain Grafis, Copywriting, E-Katalog, Kampung Tematik 


\section{PENDAHULUAN}

Periklanan disebutkan sebagai presentasi non pribadi dan upaya mempromosikan gagasan, barang atau jasa, oleh pengiklan yang harus dibayar (Kotler, 2008). Adapun beberapa fungsi periklanan diantaranya, informing, memberi informasi, dengan kata lain melalui periklanan konsumen dibuat menyadari akan hadirnya sebuah gagasan, produk atau jasa oleh pengiklan. Fungsi kedua adalah persuading, mempersuasi atau membujuk khalayak untuk mencoba gagasan, produk atau jasa yang diiklankan. Fungsi ketiga reminding, adalah mengingatkan. Hal ini berarti pengiklan selalu berusaha menyegarkan ingatan khalayak tentang gagasan, produk atau jasa yang diiklankan. Fungsi keempat adding value, memberi nilai tambah, dapat berupa inovasi, penyempurnaan atau mengubah persepsi khalayak. Fungsi kelima adalah assisting, atau mendampingi, ini berarti bahwa periklanan mampu memberi bantuan kepada perusahaan untuk memenuhi upaya pemasaran, karena periklanan merupakan salah satu komponen dari bauran pemasaran (Terence, 2003; Marhaeni K, 2008).

Produk adalah semua hal yang bisa ditawarkan kepada khalayak untuk mendapatkan perhatian, dibeli, digunakan atau dikonsumsi dan mampu memuaskan keinginan atau kebutuhan (Kotler, 2008). Berdasar pengertian tersebut dapat dikatakan bahwa produk tidak terbatas hanya pada barang dan jasa, melainkan sebuah lokasi pun dapat dikatakan produk apabila memiliki potensi yang harus dipasarkan.

Konteks produk yang diambil sebagai objek pengabdian ini adalah tempat, yaitu Kampung Tematik yang ada di Kota Semarang. Diketahui bahwa salah satu Program Pemerintah Kota Semarang dalam meningkatkan perekonomian masyarakatnya adalah dengan membentuk Kampung-Kampung Tematik di setiap Kecamatan di Kota Semarang (Pujakesuma, 2018). Dilansir dari gerbanghebat.semarangkota.go.id, Kampung Tematik adalah sebuah inovasi Pemerintah Kota Semarang yang bertujuan mengatasi berbagai permasalahan dasar yang ada di masyarakat dimana fokusnya adalah pada peningkatan kualitas lingkungan rumah tinggal warga miskin dan prasarana dasar pemukiman, dimana peran serta masyarakat dan lembaga terkait sangat besar untuk membangun karakteristik lingkungan dengan mengembangkan potensi lokal. Kampung Tematik memiliki empat pilar utama dalam gerbang hebat, diantaranya ekonomi, edukasi, ekosistem, dan etos.

Berikut data jumlah Kampung Tematik sejak dimulai program pada tahun 2016 hingga 2018.

Tabel 1. Pencapaian Pembentukan Kampung Tematik

\begin{tabular}{cc}
\hline Tahun & Jumlah \\
\hline 2016 & 32 \\
2017 & 80 \\
2018 & 65 \\
TOTAL & 177 \\
\hline
\end{tabular}

(Sumber: Bapeda Kota Semarang, 2019)

Di sisi lain, pemasaran digital muncul karena dunia sudah memasuki era digital, dimana masyarakatnya dapat saling berkomunikasi dengan dekat meskipun dari jarak jauh dan mampu mendapatkan informasi secara real time tanpa harus membaca buku. melakukan berbagai teknologi telah memaksimalkan potensi desain grafis. Secara umum pemasaran digital memaksimalkan penggunaan teknologi moderen untuk membantu kegiatan pemasaran dalam meningkatkan pengetahuan pelanggan dengan mencocokkan apa kebutuhan dan keinginan pelanggan (Chaffey, 2016).

Komunikasi visual dinobatkan sebagai metode komunikasi utama untuk mempromosikan produk atau merk dalam pemasaran digital. Sub kategori penting komunikasi visual yaitu Desain Grafis merupakan media yang makin populer dan muncul dari akar keilmuan seni dan diadopsi secara luas setelah penemuan teknik mencetak dan alat percetakan (Philip, 2018). Oleh karena itu perusahaan maupun institusi apapun mempunyai kebutuhan yang sangat besar akan desain grafis sebagai media dalam berkomunikasi pada era digital sekarang ini, bahkan ada divisi khusus yang menangani bidang tersebut.

Menilik pada perkembangan dunia pemasaran, kampung tematik bentukan Pemerintah Kota Semarang dinilai berhasil, karena beberapa lokasi telah mampu menemukan dan menyepakati potensi yang mereka miliki. Potensi-potensi yang ada, baik berupa produk maupun lokasi wisata yang 
menarik masih sangat sedikit diketahui oleh khalayak luas, bahkan oleh masyarakat Kota Semarang itu sendiri. Hal ini yang menjadi hambatan dalam kemajuan program kampung tematik.

Generasi muda dianggap sebagai generasi yang paling melek digital, bahkan mereka disebut sebagai digital native (Betz, 2019). Hal ini menjadi dasar mengapa pengetahuan dan pembelajaran untuk bisa bersaing di era digital menjadi penting. Menilik pada latar belakang yang telah diuraikan, kebutuhan generasi muda untuk memiliki kemampuan desain grafis merupakan hal yang sangat mendukung kemajuan kampung tematik. Melalui pengaplikasian desain grafis pada E-Katalog untuk memperkenalkan kampung Tematik di wilayah mereka, diharap mampu mendukung program yang telah diupayakan oleh pemerintah Kota Semarang.

Hasil wawancara pendahuluan diketahui bahwa anggota Karang Taruna yang merupakan perwakilan dari masing-masing kelurahan dan kecamatan belum banyak mengetahui tentang tujuan program Kampung Tematik, sehingga belum melakukan upaya nyata untuk mendukung pengembangannya.

Berdasar pada latar belakang dan situasi yang terjadi, Pelatihan pengaplikasian desain grafis dan copywriting pada E-Katalog Kampung Tematik Kota Semarang akan dilakukan untuk Karang Taruna Kota Semarang.

\section{METODE PELAKSANAAN}

Kegiatan Pelatihan Pengaplikasian Desain Grafis pada E-Katalog untuk Karang Taruna Kota Semarang mengalami perubahan dalam pelaksanaannya karena harus disesuaikan dengan kenormalan baru di masa pandemi Covid 19, sehingga pengabdian kepada masyarakat ini dilakukan secara daring.

\section{Waktu dan Tempat Pelaksanaan}

Kegiatan pengabdian kepada masyarakat yang bertajuk "Workshop E-Katalog, Karang Taruna Bersatu Kampung Tematik Maju" dilaksanakan bertepatan dengan peringatan hari Sumpah Pemuda, 28 Oktober 2020, pukul 09.00-12.00 WIB. Kegiatan ini dilakukan secara daring melalui aplikasi google meet.

\begin{abstract}
Alat dan Bahan:
Adapun alat dan bahan yang digunakan dalam workshop E-Katalog diantaranya, laptop, smartphone, ring light, microphonem headset aplikasi google meet, aplikasi whatsapp, dan aplikasi adobe premier. Bahan atau materi yang digunakan adalah tutorial desain grafis dan teknik copywriting.

Selain itu kuesioner pre test dan post test menggunakan googleform, diolah menggunakan Microsoft Excel.
\end{abstract}

\section{Langkah Pelaksanaan}

Berikut tahapan kegiatan Pelatihan Pengaplikasian Desain Grafis pada E-Katalog untuk Karang Taruna dimana acara dikemas dengan tajuk Workshop E-Katalog.

\section{Persiapan}

Kegiatan workshop dipromosikan dengan poster digital yang disebarluaskan melalui media sosial. Selain memberikan E-sertifikat, tim pengabdian juga memberikan hadiah uang tunai untuk dua desain terbaik. Hal ini dilakukan guna menarik peserta.

Proses Pendaftaran peserta dilakukan melalui link google form, yang disebarluaskan melalui media sosial. Formulir pendaftaran dilengkapi dengan pertanyaan pre test.

Persiapan Pre Event adalah dengan membuat grup Whatsapp untuk seluruh peserta yang telah mendafatar. Grup Whatsapp difungsikan untuk memberikan informasi terkait teknis pelaksanaan workshop.

\section{Pelaksanaan}

Pelaksanaan dilakukan secara daring. Berlaku sebagai moderator adalah Naiza Rosalia, S.Sos, Msi (Presenter \& Dosen Ilmu Komunikasi Universitas Dian Nuswantoro). Narasumber pertama Choirul Ulil Albab, M.I.Kom (Presenter \& Dosen Ilmu Komunikasi Universitas Dian Nuswantoro), memberikan materi tentang copywriting. Narasumber kedua yang merupakan ketua tim pengabdian, Muhammad Hasan Basori, M.A (Graphic Designer \& Dosen Ilmu Komunikasi Universitas Dian Nuswantoro), memberikan materi utama yaitu desain grafis. Kegiatan workshop berjalan dengan baik sesuai rundown

Selain pemberian materi, workshop juga melakukan sesi praktek. Praktek desain grafis dan copywriting dilakukan menggunakan template yang telah dibagikan sebelumnya. Hal ini dilakukan untuk efisiensi waktu berkaitan 
dengan penggunaan kuota internet peserta. Selama proses praktek, moderator membuka sesi Tanya jawab yang juga berlangsung dengan santai namun tepat sasaran karena antusias tinggi dari peserta.

Post event dilakukan dengan memberikan link kuesioner pre test sebagai alat untuk mengetahui efektifitas dari workshop. Pengisian pre test merupakan salah satu syarat peserta dapat memperoleh E-Sertifikat.

Pengumuman pemenang desain terbaik diumumkan pada tanggal 19 Oktober 2020. Dua pemenang diantaranya, Taufik Ariya dan Agasta Irena Effendi. Pengumuman dilakukan melalui grup Whatsapp. Hadiah diberikan melalui bank transfer.

\section{Monitoring Evaluasi}

Proses monitoring yang ada di workshop ini dilakukan internal sendiri oleh Mitra pengabdian yaitu Ketua Karang Taruna Kartini. Monitor internal hanya menggunakan catatan sederhana. Aspek yang di monitoring belum mencakup seluruh komponen-komponen pelatihan. Manajemen pelatihan yang ada di Mitra pengabdian belum dikelola secara baik. Kegiatan monitoring ini dilaksanakan selama pelaksanaan kegiatan workshop. Pengambilan kesimpulan didasarkan pada proses monitoring secara keseluruhan, jika baik akan berlanjut. Namun, jika tidak akan tetap dilanjutkan dengan adanya perbaikan pada kekurangan yang ada. Pelaporan yang disusun oleh pihak internal hanya berupa catatan dan secara lisan kepada tim pengabdian.

Proses evaluasi program pelatihan dilakukan oleh tim pengabdian sendiri, Namun, teknik yang digunakan oleh evaluator ditunjang dengan kuesioner google form, evaluator juga menggunakan catatan dan dokumentasi. Evaluasi program ini dilakukan di akhir rangkaian kegiatan pelatihan. Belum ada kompetensi khusus yang harus dimiliki oleh seorang evaluator, yang terpenting adalah menguasai topik workshop terkait desain EKatalog.

Aspek yang dievaluasi adalah proses awal yaitu proses penyampaian materi sampai pada praktik yang dilakukan oleh peserta dan hasil produk peserta pelatihan. Berdasarkan yang disampaikan oleh evaluator, aspek yang di evaluasi hanya mencakup pada 3 hal yaitu masukan sarana berupa persiapan alat dan bahan, proses pendidikan melalui pembelajaran yaitu penyampaian materi oleh narasumber sampai pada praktik langsung para peserta. Ketiga adalah keluaran yaitu kualitas dari desain layout yang dihasilkan oleh para peserta.

Pengolahan data yang dilakukan menggunakan pendekatan kuntitatif dari hasil post test. Evaluator mendeskripsikan data temuan saat evaluasi. Kemudian data tersebut diperiksa kembali jika masih ada yang kurang. Analisis data pada pendekatan kuantitatif dilakukan melalui tiga tahap yaitu reduksi data, display data dan verifikasi data. Pada tahap reduksi data, evaluator mengumpulkan seluruh data yang diperoleh dan merangkumnya. Kemudian display data dengan mendeskripsikan dalam bentuk naratif, kemudian verifikasi data dengan meneliti kembali data yang sudah dideskripsikan, dan pada tahap ini lah evaluator akan menarik kesimpulan.

\section{$\underline{\text { Keberlanjutan }}$}

Hasil desain grafis para peserta workshop akan dikumpulkan dan dikompilasi menjadi EKatalog Kampong Tematik edisi pertama. Hal ini dilakukan atas persetujuan peserta. Harapannya setiap tahun ada kegiatan-kegiatan workshop yang akan menghasilkan E-Katalog kampung tematik edisi-edisi terbaru berikutnya. Para peserta workshop bisa menjadi kontributor E-Katalog Kampung Tematik.

\section{Pelaporan}

Pertama, bentuk laporan lengkap (teknis) yaitu laporan yang secara lengkap berisi tentang pelaksanaan program beserta hasilnya dengan penulisan yang memenuhi asas-asas ilmiah. Kedua, laporan ringkasan yaitu bentuk laporan yang diperuntukkan bagi para pihak yang berkepentingan. Laporan ringkasan dapat berupa laporan tersendiri atau bagian dari laporan lengkap. Laporan ringkasan berisi informasi singkat tentang tujuan, prosedur, temuan-temuan, pertimbangan-pertimbangan dan tindak lanjut program.

\section{HASIL DAN PEMBAHASAN}

Peserta workshop berjumlah 32 orang, ini merupakan anggota Karang Taruna Kota Semarang yang berusia 18-35 tahun. Jumlah tersebut merupakan perwakilan dari 16 keluarahan yang ada di Kota Semarang. Berdasarkan hasil pre test, diketahui beberapa hal sebagai berikut, 


\section{Pemahaman Desain Grafis}

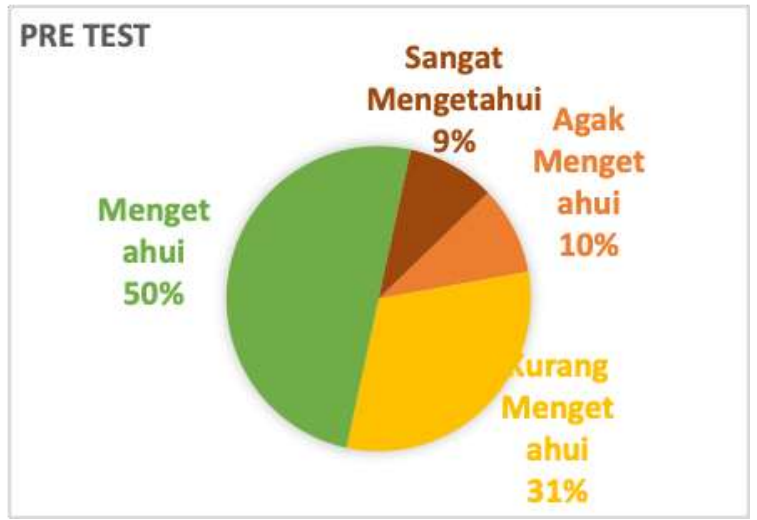

Gambar 1. Pengetahuan mengenai desain grafis sebelum workshop

Diketahui $50 \%$ atau 16 peserta sudah memiliki pengetahuan terkait desain grafis, $9 \%$ sangat mengetahui. 32\% kurang mengetahui dan $10 \%$ lainnya mengaku agak mengetahui. Generasi muda saat ini sangat dekat dengan teknologi, utamanya terkait dengan desain grafis karena saat ini tuntutan untuk desain grafis sangat dibutuhkan dalam segala aspek kehidupan (Gambar 1).

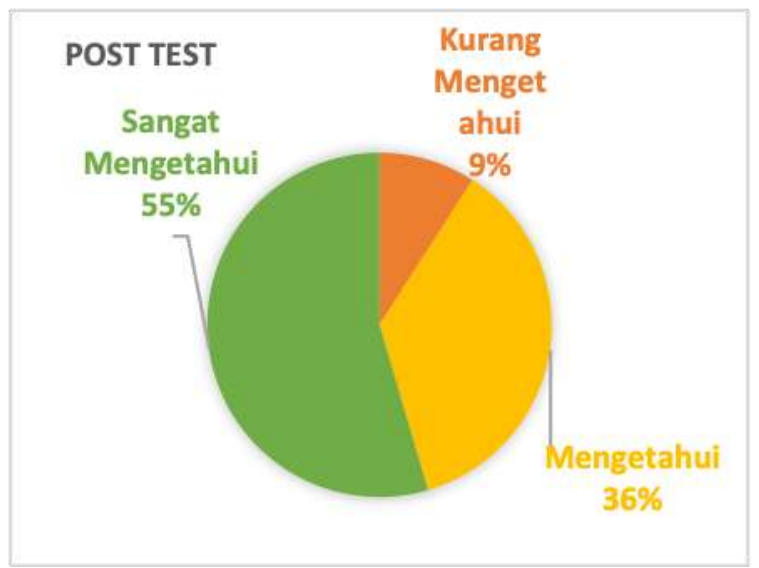

Gambar 2. Pengetahuan mengenai desain grafis setelah workshop

Tujuan dari kegiatan pengabdian masyarakat dengan pemberian pelatihan kepada karang taruna kota Semarang ini berhasil meningkatkan pemahaman mereka mengenai desain grafis. Setelah mengikuti pelatihan ini, $55 \%$ peserta mengaku sangat memahami desain grafis mulai dari program apa saja yang digunakan, tools yang tersedia, penguasaan teknik desain grafis, hingga pembuatan desain e-katalog. Sebelumnya peserta yang kurang mengetahui desain grafis sebesar $32 \%$ setelah mengikuti pelatihan ini turun menjadi 9\% (Gambar 2).

\section{Pengetahuan Desain Grafis}

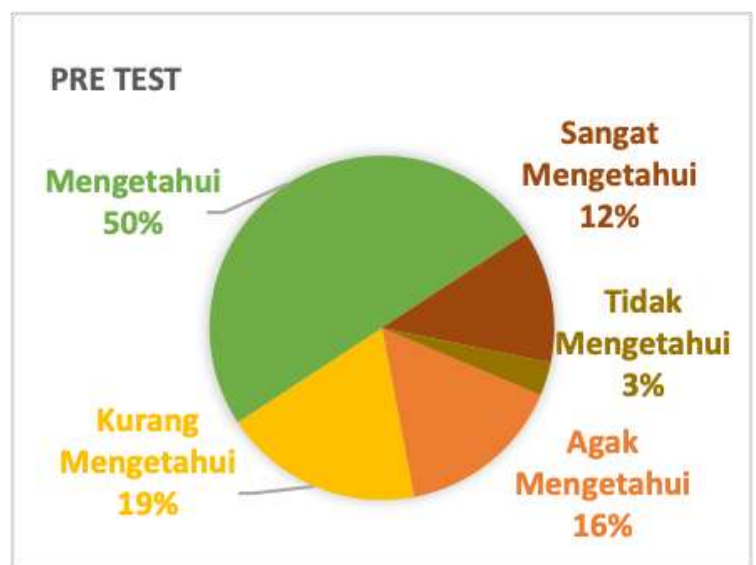

Gambar 3. Pengetahuan desain grafis dapat digunakan untuk E-Catalog sebelum workshop

Pengetahuan mengenai desain grafis di kalangan pemuda karang taruna Kota Semarang bisa dikatakan sudah cukup baik. 32 peserta yang mengikuti workshop, hanya 1 orang atau $3 \%$ saja yang tidak mengetahui bahwa pembuatan e-katalog dibuat melalui proses desain grafis. $50 \%$ peserta juga mengaku sudah mengetahui hal ini.

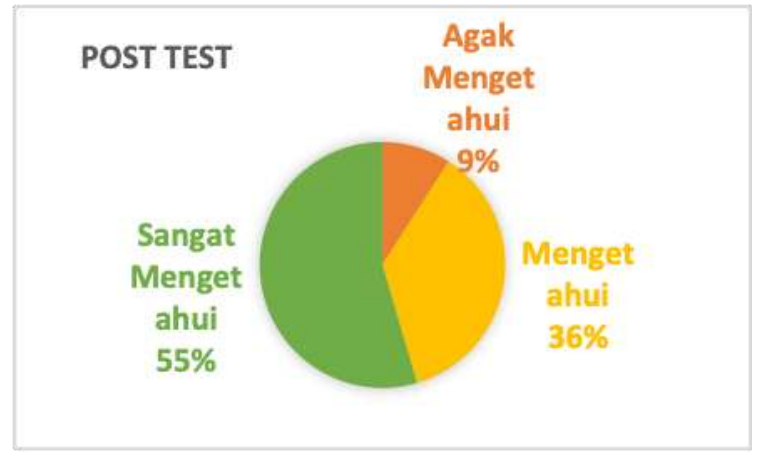

Gambar 4. Pengetahuan desain grafis dapat digunakan untuk E-Catalog setelah workshop

Setelah workshop ini para peserta menjadi lebih tahu bagaimana pengaplikasian desain grafis dalam membuat e-katalog. Terbukti dengan $55 \%$ peserta mengaku sangat mengetahui dan $36 \%$ peserta mengaku mengetahui tentang hal ini.

\section{Teknik Penerapan Desain Grafis}

Pemuda karang taruna Kota Semarang sebagian besar kurang mengetahui bagaimana elemen-elemen desain grafis. 


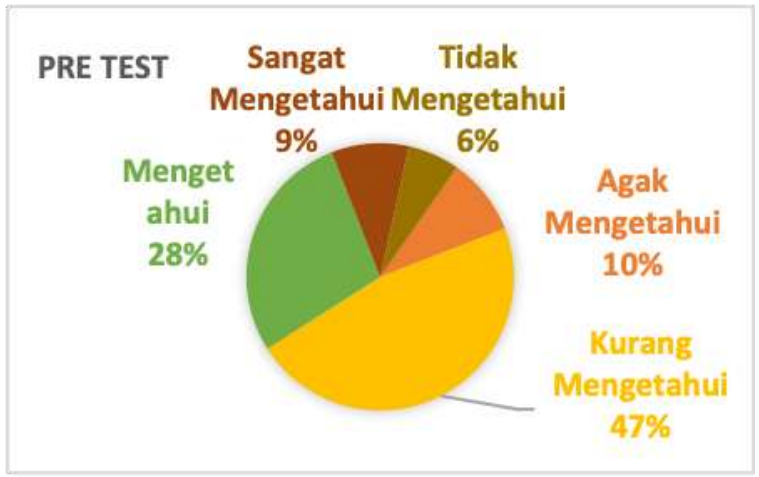

Gambar 5. Pengetahuan mengenai elemen -elemen desain grafis sebelum workshop

Berdasarkan Gambar 5 diketahui bahwa sebanyak $47 \%$ atau 15 orang mengaku kurang mengetahui elemen-elemen desain grafis. Hanya $28 \%$ atau sekitar 9 orang yang mengetahui elemen-elemennya. Komposisi gambar, kontras warna, dan elemen-elemen lainnnya mendukung sebuah karya grafis memiliki kualitas dan estetika yang baik.

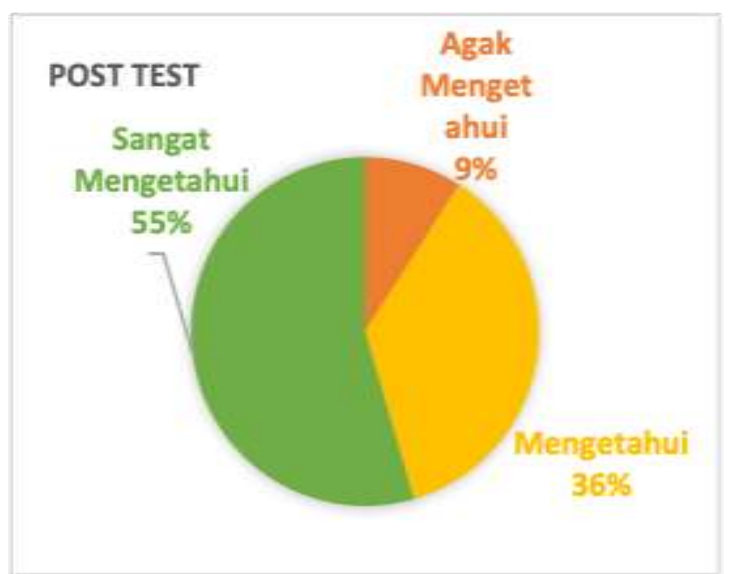

Gambar 6. Pengetahuan mengenai elemen -elemen desain grafis setelah workshop

Setelah para peserta mengikuti workshop, $55 \%$ peserta mengaku sangat mengetahui elemen elemen ini. Ketua kegiatan sekaligus pemateri workshop, Hasan Basori, MA memberikan penjelasan yang sangat detil dan komprehensif dalam menjelaskan elemenelemen apa saja yang perlu diperhatikan dalam membuat sebuah karya grafis yang memukau. Setelah workshop ini pemuda karang taruna Kota Semarang sudah tidak ada yang mengaku tidak mengetahui atau kurang mengetahui mengenai elemen-elemen desain grafis.

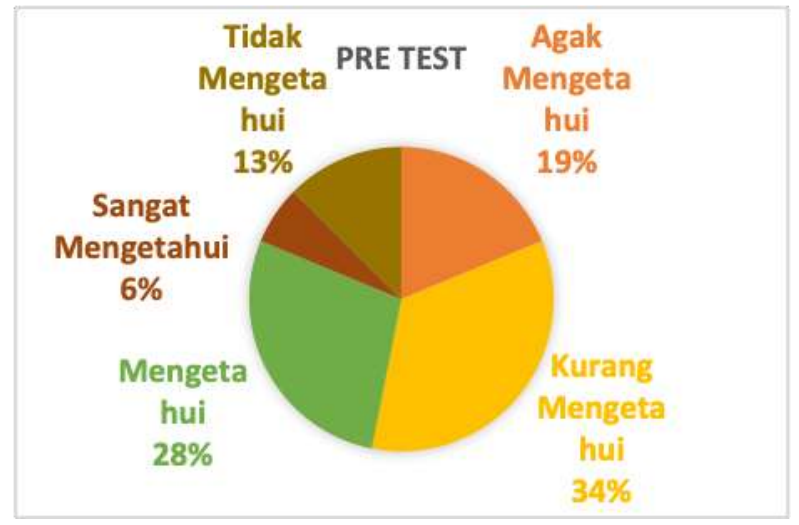

Gambar 7. Pengetahuan prinsip-prinsip desain grafis sebelum workshop

Selain elemen-elemen desain grafis, penerapan prinsip-prinsip desain grafis juga harus diketahui saat kita membuat e-katalog. Sebelum workshop, hanya $28 \%$ atau 9 peserta yang mengetahui prinsip ini. Meski berisikan banyak informasi, sebuah katalog juga harus tetap menarik ketika dipandang, sehingga dapat menimbulkan hasrat untuk mengunjungi tempat yang tertera di katalog.

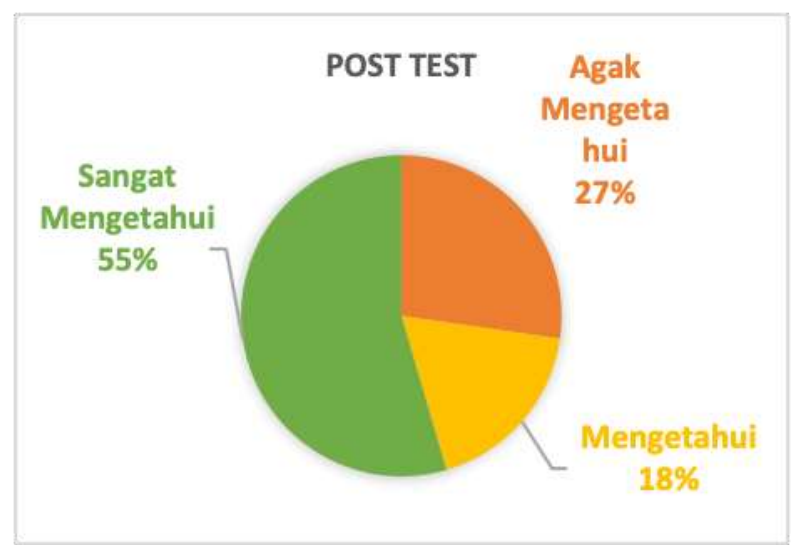

Gambar 8. Pengetahuan prinsip-prinsip desain grafis setelah workshop

Setelah workshop pelatihan desain grafis untuk pemuda karang taruna Kota Semarang pengetahuan mereka terkait prinsip-prinsip desain grafis meningkat. Ini terbukti dari sebelumnya hanya $6 \%$ peserta yang sangat mengetahui dan $28 \%$ peserta yang mengetaui prinsip ini, setelah menjalani workshop ini, $55 \%$ peserta mengaku sangat mengetahui dan $27 \%$ peserta mengakui mengetahui prinsipprinsip yang harus diterapkan dalam desain grafis. 


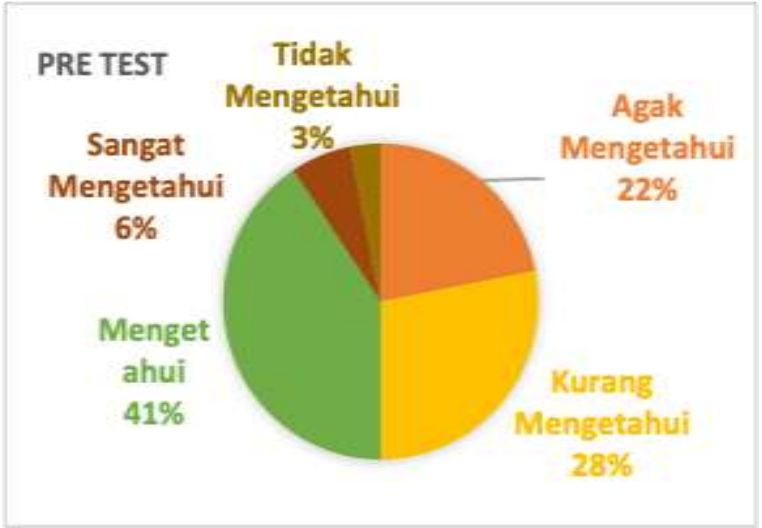

Gambar 9. Pengetahuan mengenai layout sebelum workshop

Layout merupakan istilah teknis yang biasa digunakan untuk menggambarkan tata letak. Untuk membuat sebuah katalog yang baik dan menarik, aspek tata letak ini sangat menentukan. Mengetahui mengenai layout adalah hal dasar yang harus diketahui seseorang sebelum membuat katalog. Para peserta workshop sudah tidak asing mengenai istilah layout, $41 \%$ peserta sudah mengetahui mengenai istilah ini. Hanya 1 orang atau 3\% peserta yang tidak mengetahui istilah ini.

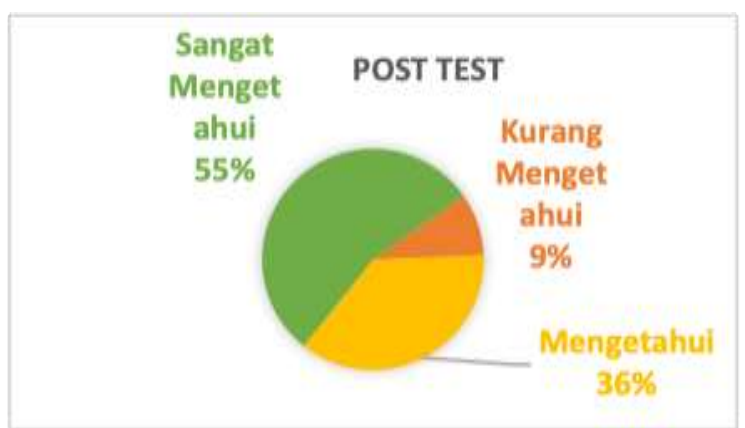

Gambar 10. Pengetahuan mengenai layout setelah workshop

Setelah dilakukan workshop dan diberikan penjelasan mengenai layout atau tata letak dan aspek-aspek pendukungnya, peserta workshop $55 \%$ atau 18 orang peserta mengaku sangat mengetahui ilmu tata letak atau layout. Semua peserta workshop sudah tidak ada yang tidak mengetahui mengenai aspek tata letak dalam pembuatan sebuah katalog.

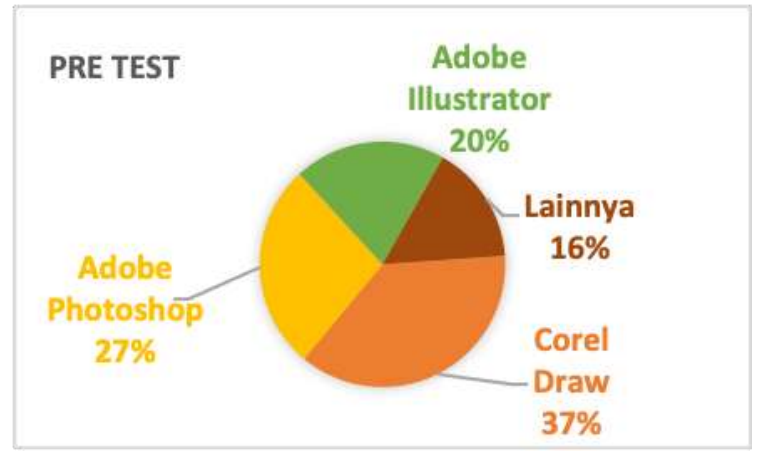

Gambar 11. Software desain grafis yang biasa digunakan peserta sebelum workshop

Banyak aplikasi atau program yang digunakan untuk membuat desain grafis. Paling banyak atau sebesar $41 \%$ peserta menggunakan Corel Draw, 29\% menggunakan Adobe Photoshop, $13 \%$ menggunakan Adobe Illustrator, dan $17 \%$ menggunakan software lainnya seperti Canva, Adobe Indisign, dan Adobe After Effect. Dalam workshop ini, peserta di jelaskan mengenai fungsi-fungsi dan spesifikasi dari setiap software yang digunakan.

Peserta juga secara langsungs sharing dengan pemateri terkait kelebihan dan kekurangan setiap software. Hasan Basori, MA menjelaskan bahwa peserta lebih baik tidak menggunakan Adobe Photoshop untuk membuat desain, karena Adobe Photoshop ini fungsinya adalah untuk editing foto. Ia juga menambahkan penggunaan Adobe Illustrator lebih mudah dan sesuai untuk membuat desain grafis seperti katalog.

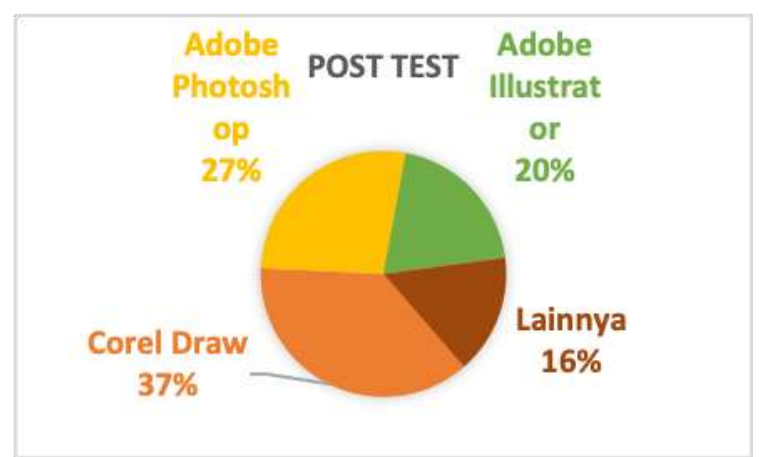

Gambar 12. Software desain grafis yang biasa digunakan peserta setelah workshop 
Setelah workshop, pemuda karang taruna kota Semarang menjadi lebih memahami perangkat lunak untuk membuat desain. Hasilnya pengguna Adobe Illustrator sebagai perangkat lunak yang dinilai lebih mudah diaplikasikan untuk membuat desain meningkat. Sebelumnya $13 \%$ peserta yang menggunakan ini, setelah workshop naik menjadi 20\%. Software Corel Draw masih menjadi perangkat lunak yang paling banyak diminati peserta.

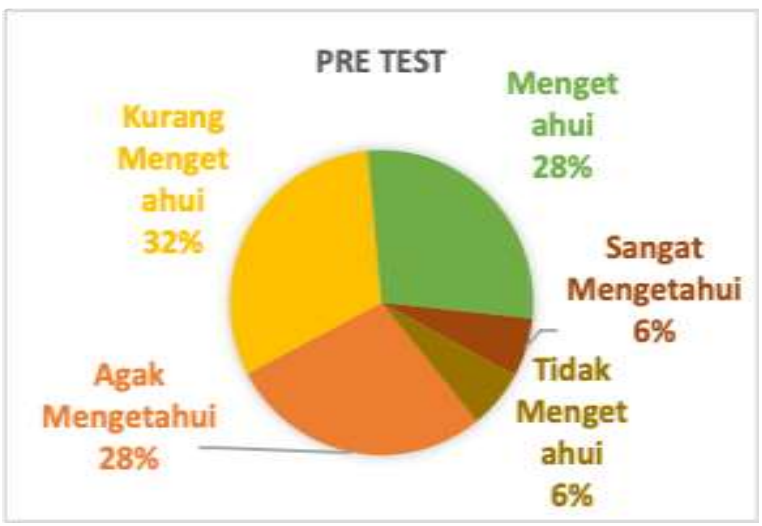

Gambar 13. Pengetahuan mengenai Adobe Illustrator sebelum workshop

Pemuda karang taruna Kota Semarang sebagai peserta workshop awalnya hanya $28 \%$ saja yang mengetahui software Adobe Illustrator. Berdasar gambar 13, sebagian besar peserta juga mengatakan bahwa mereka kurang mengetahui adanya software Adobe Illustrator untuk digunakan membuat desain grafis. Adobe Illustrator sendiri merupakan sebuah program editor grafis vektor yang terkemuka. Program ini dikembangkan dan dipasarkan oleh Adobe Systems. Hasan Basori, MA menggunakan software Adobe Illustrator CS 6 yang merupakan pembaruan ke-16.

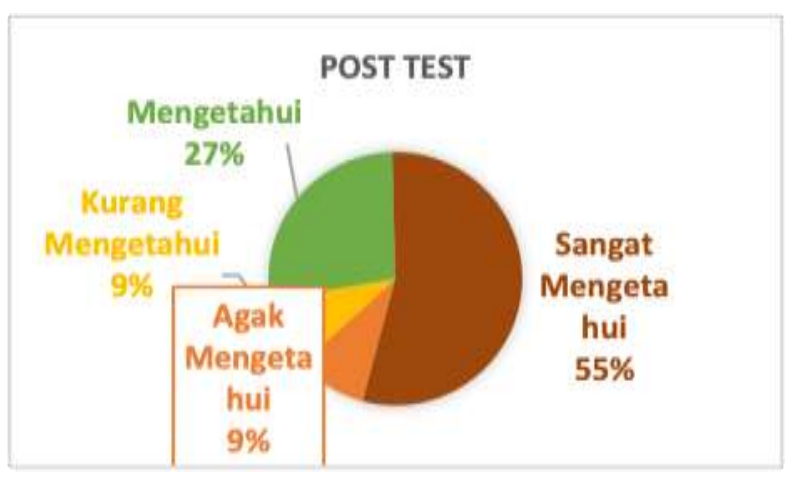

Gambar 14. Pengetahuan mengenai Adobe Illustrator setelah workshop
Setelah mengikuti workshop desain grafis, sebagian besar peserta sudah sangat mengetahui software Adobe Illustrator, bahkan mereka sudah mencoba dan menggunakannya untuk membuat desain e-katalog. Para peserta workshop juga sudah mengenal tools atau piranti lunak yang bisa mereka gunakan dalam membuat desain grafis. Mereka juga sudah bisa mengombinasikan grafis dengan gambar dan tulisan serta membuat gradasi warna yang menarik.

Dalam pembuatan e-katalog kemampuan desain grafis sangat diperlukan. Aplikasi dan software desain grafis memang dapat membantu untuk membuat katalog yang baik, namun yang terpenting adalah bagaimana seseorang mengemas dan membuat konsep katalog yang dapat menarik perhatian pembacanya. Aspek ini juga diajarkan pada workshop pembuatan e-katalog melalui teknik copywriting.

\section{Teknik Copywriting}

Dua produk yang sama, akan memiliki nasib yang berbeda bila dipasarkan dengan teknik yang berbeda. Teknik copywriting membantu kita untuk memperkenalkan produk, jasa, tempat wisata, atau layanan yang kita miliki kepada masyarakat luas. Copywriting membatu kita untuk membuat perencanaan konsep sebuah alat promosi yang sangat komprehensif. Teknik ini sangat dibutuhkan dalam membuat katalog sehingga pengemasan kontennya tertata dengan baik.

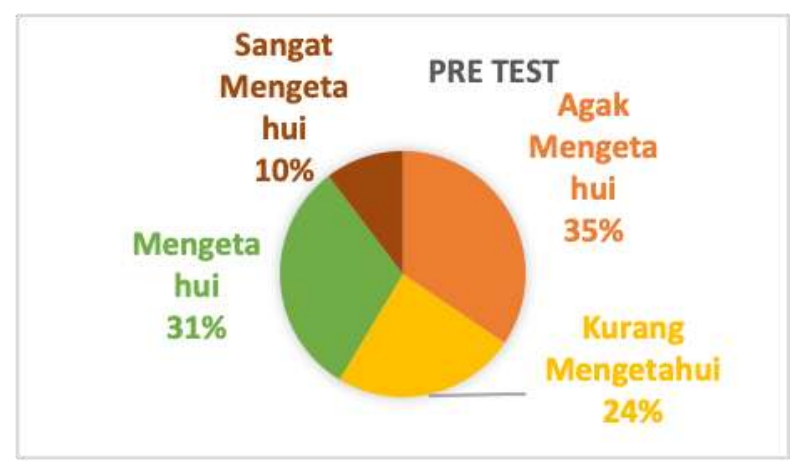

Gambar 15. Pengetahuan definisi copywriting sebelum workshop

Sebelum workshop, hanya $10 \%$ atau tiga orang peserta yang sangat mengetahui teknik copywriting. Sedangkan $24 \%$ mengaku bahwa ia kurang mengetahui teknik copywriting. Sebagian besar generasi muda saat ini memang sudah familiar dengan istilah ini, $31 \%$ mengaku mengetahui dan $35 \%$ mengaku agak 
mengetahui. Istilah copywriting sangat popular di Indonesia saat ini, namun belum banyak yang tahu bagaimana teknik penggunaannya.

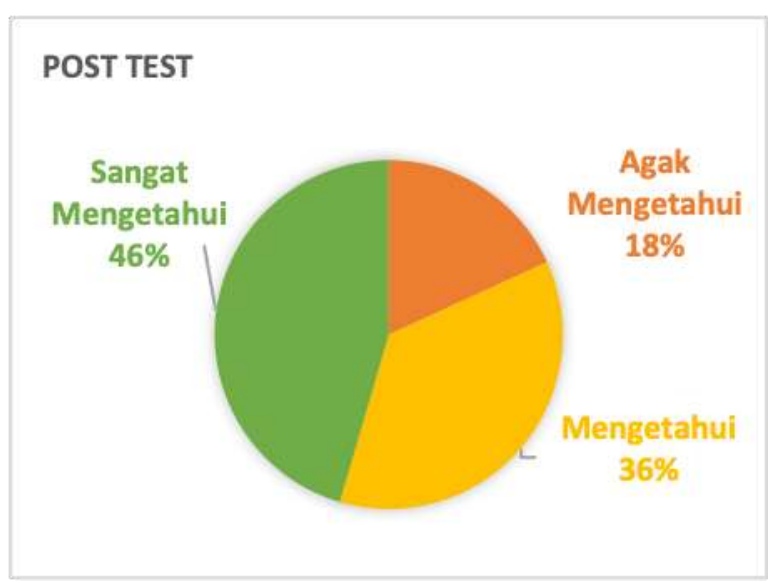

Gambar 16. Pengetahuan definisi copywriting setelah workshop

Copywriting merupakan salah satu teknik seni menulis yang bertujuan untuk mendapatkan respon baik dari audiensnya. Media dalam copywriting sangat beragam tidak hanya dalam bentuk tulisan, namun bisa menggunakan gambar atau video sesuai kebutuhan dan target yang dicapai. Setelah mengikuti workshop e katalog, $46 \%$ peserta mengaku sangat mengetahui definisi dari copywriting.

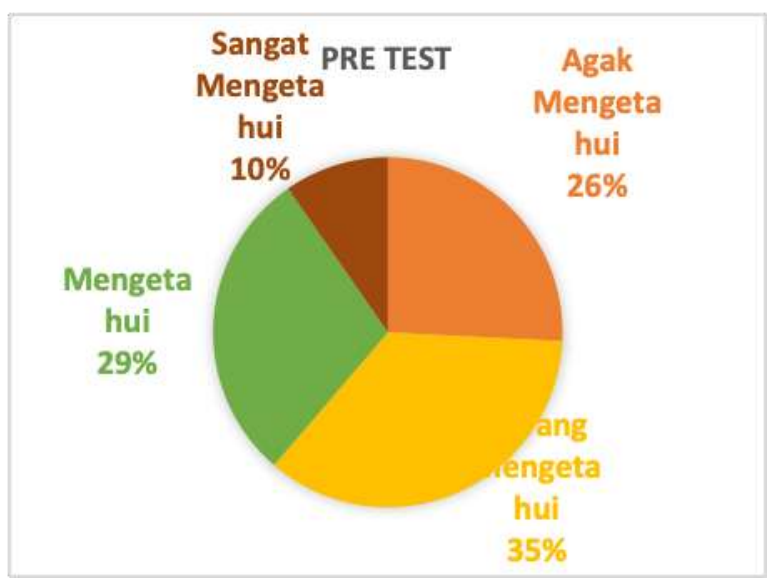

Gambar 17. Pengetahuan fungsi copywriting sebelum workshop

Sesuai dengan tujuan digunakan dari teknik copywriting, fungsi dari teknik ini sangat kompleks. Fungsi utama teknik ini adalah untuk meningkatkan konversi. Konversi adalah sikap masyarakat yang diharapkan oleh pembuat copy, seperti membeli, mengunjungi, mendaftar, mendownload dan masih banyak lagi. Sebelum mengikuti workshop ini, $35 \%$ peserta kurang mengetahui fungsi dari copywriting dan hanya $10 \%$ atau 3 orang saja yang mengaku sangat mengetahui.

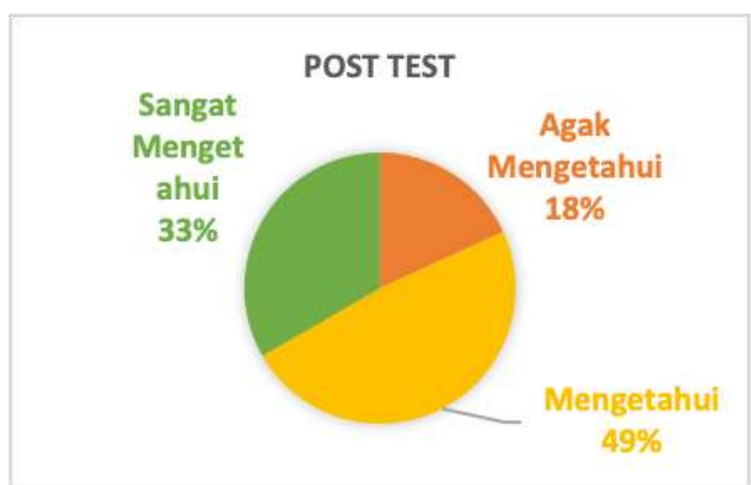

Gambar 18. Pengetahuan fungsi copywriting setelah workshop

Para pemuda karang taruna Kota Semarang sebagai peserta dalam workshop ini, dapat mengeksplor lebih jauh pengetahuan mereka terkait dengan bagaimana pembuatan sebuah katalog. Fungsi copywriting menjadi salah satu hal yang sangat penting bagi bekal mereka untuk bisa menambah pengetahuan mereka. Saat ini $49 \%$ peserta sudah mengetahui fungsi copywiting dan $33 \%$ mengaku sangat mengetahuinya. Penerapan fungsi ini juga langsung mereka terapkan saat praktk langsung pembuatan e-katalog.

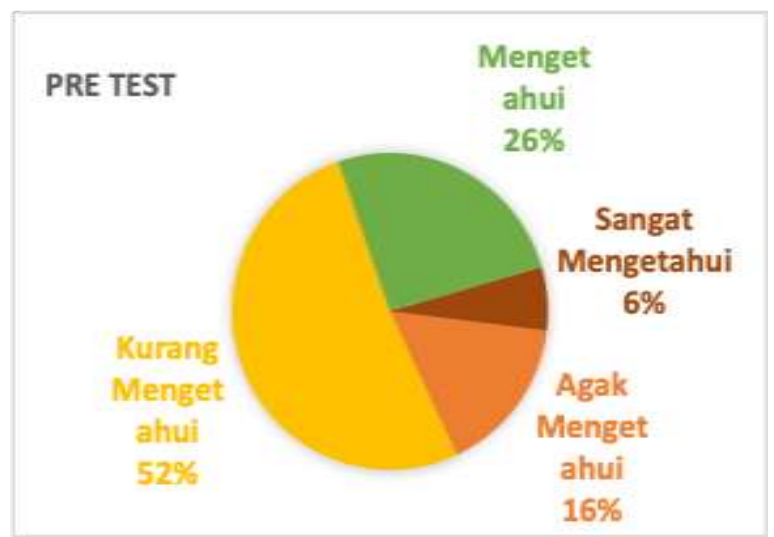

Gambar 19. Pengetahuan tahapan copywriting sebelum workshop

Membuat copywriting memang tidak bisa dalam waktu sekejap, membutuhkan banyak riset dan pematangan konsep. Tahadap dalam pembuatan copywriting biasanya diawali dengan menerapkan mindset atau pola pikir seorang copy writer yang kreatif, terfokus, dan peduli terhadap calon customernya. Hal ini ternyata banyak yang belum mengetahuinya, 
52\% peserta mengaku kurang mengetahui tahapan-tahapan pembuatan copywriting.

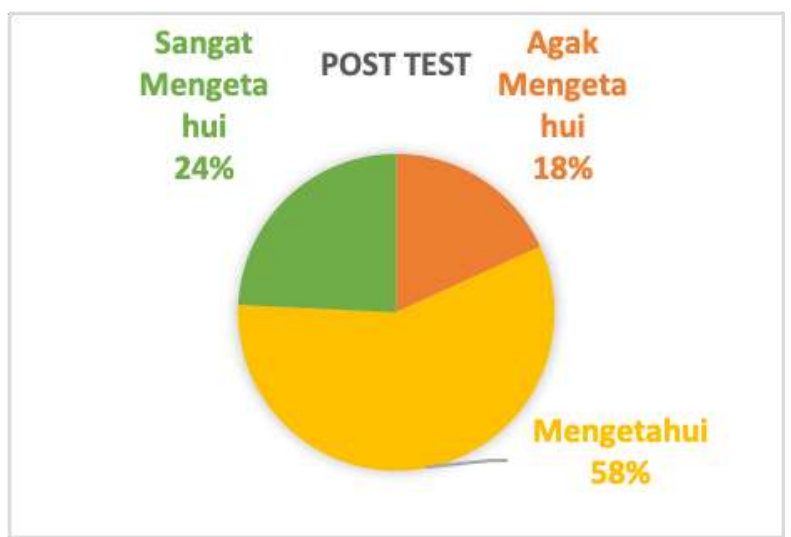

Gambar 20. Pengetahuan tahapan copywriting setelah workshop

Berdasar Gambar 20, setelah mengikuti workshop ini peserta menjadi tahu bagaimana sebuah copy ini dibuat. Diawali dengan menerpakan pola piker seorang copy writer, kemudian menyusun strategi dengan formula AIDA (Attention, Interest, Desire, Action), dan membuat landing page dengan teknik desain grafis. Saat ini pemuda karang taruna Kota Semarang memiliki pengetahuan mengenai teknik copywriting lebih baik. Setelah workshop ini 58\% responden mengaku sudah mengetahui tahapan pembuatan copywriting, 24 $\%$ bahkan mengaku sangat mengetahui dan $18 \%$ agak mengetahui.

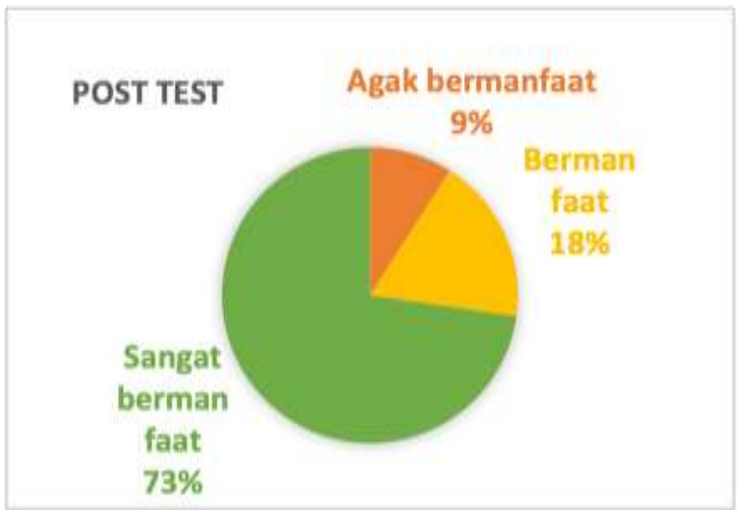

Gambar 21. Manfaat workshop desain grafis ekatalog

Menurut Gambar 21, secara keseluruhan workshop e-katalog ini sangat bermanfaat bagi karang taruna Kota Semarang untuk memajukan pariwisata Kota Semarang melalui kampung tematiknya. Materi terkait copywriting dan pelatihan desain grafis sangat memberikan pengetahuan lebih luas terkait dengan 2 ilmu ini. Sebagian besar peserta mengaku bahwa kegiatan ini sangat bermenfaat, sebanyak $73 \%$ peserta mengakui itu. Mereka berharap kegiatan ini dapat diselenggarakan lagi usai pandemi sehingga bisa dijalankan dengan tatap muka.

\section{Peluang dan Tantangan Desain E Katalog}

Digitalisasi merupakan keniscayaan yang tidak dapat dihindari oleh aspek kehidupan manapun. Konvergensi media memungkinkan masyarakat mengakses segala sesuatu dan memenuhi kebutuhan hidupnya dengan perangkat digital. Peluang inilah yang harus diperhatikan oleh industri agar tetap bertahap dalam perkembangan teknologi ini.

Pemasaran produk menggunakan katalog sangat membantu industri untuk memperkenalkan produknya, baik itu barang atau jasa kepada calon konsumen. Fenomena paperless merubah dinamika kehidupan media secara global. Terlebih kemunculan media sosial membuka peluang baru dalam pemasaran produk di media digital.

Pembuatan E-Katalog yang lebih mudah membuat para pebisnis mulai banyak menggunakan e-katalog ini. Di sisi lain biaya yang dilekuarkan lebih sedikit karena tidak melalui proses cetak. Distribusi E-Katalog ini saat ini lebih mudah dan murah karena tidak menggunakan jasa pengriman, langsung dengan menggunakan smartphone atau gadget lain yang dimiliki pebisnis tersebut.

Saat ini hampir semua bisnis sudah memiliki e-katalog dengan berbagai macam bentuk, seperti e-magazine, poster, atau video. Membuatnya juga tergolong mudah bagi yang mengerti ilmu tentang desain.

Di sisi lain, e-katalog belum bisa menjangkau semua lapisan masyarakat. Kelompok lansia atau di atas 50 tahun menjadi kelompok yang sulit menerima kebaruan teknologi ini. Selain itu aspek kewilayahan yang belum memiliki jaringan internet yang baik juga belum bisa menerima dan mengaplikasikan e-katalog dalam bisnis atau usaha mereka.

Adapun luaran pengabdian kepada masyarakat ini adalah publikasi di media online dan media sosial. Diketahui bahwa pengabdian kepada masyarakat memiliki hakekat diantaranya, (1) Pusat pengkajian dan pengembangan IPTEKS, (2) Pusat pembaharuan dan modernisasi, (3) Pusat kebudayaan masyarakat yang memiliki perguruan tinggi, (4) Sumber pakar status 
sosial, dan (5) Sumber belajar mahasiswa (Riduwan, 2016).

Berikut publikasi di media online AYOSEMARANG.COM yang dapat diakses melalui tautan https://www.ayosemarang.com/ $\mathrm{read} / 2020 / 10 / 28 / 66087 /$ udinus-gelarworkshop-e-katalog-untuk-karang-taruna.

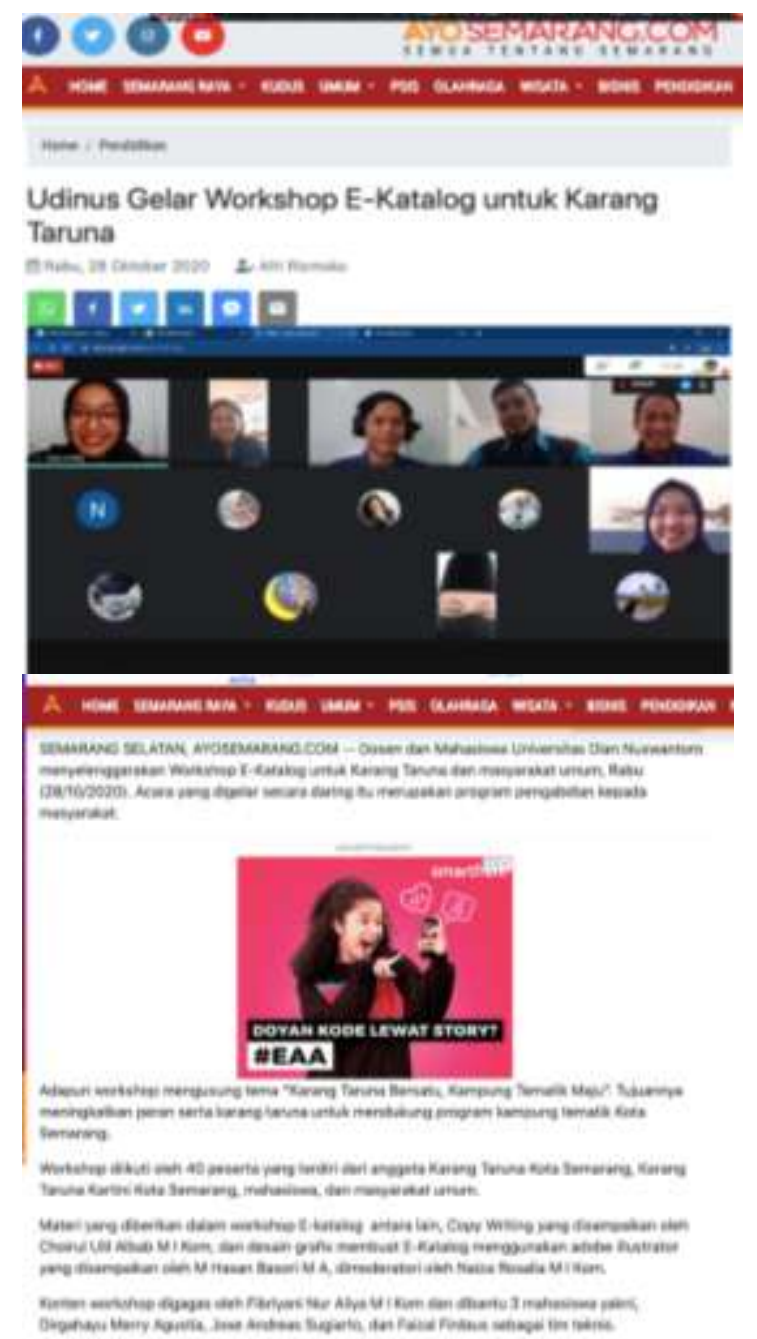

Gambar 22. Publikasi Media Online AYOSEMARANG.COM

Publikasi lainnya melalui media sosial Instagram.

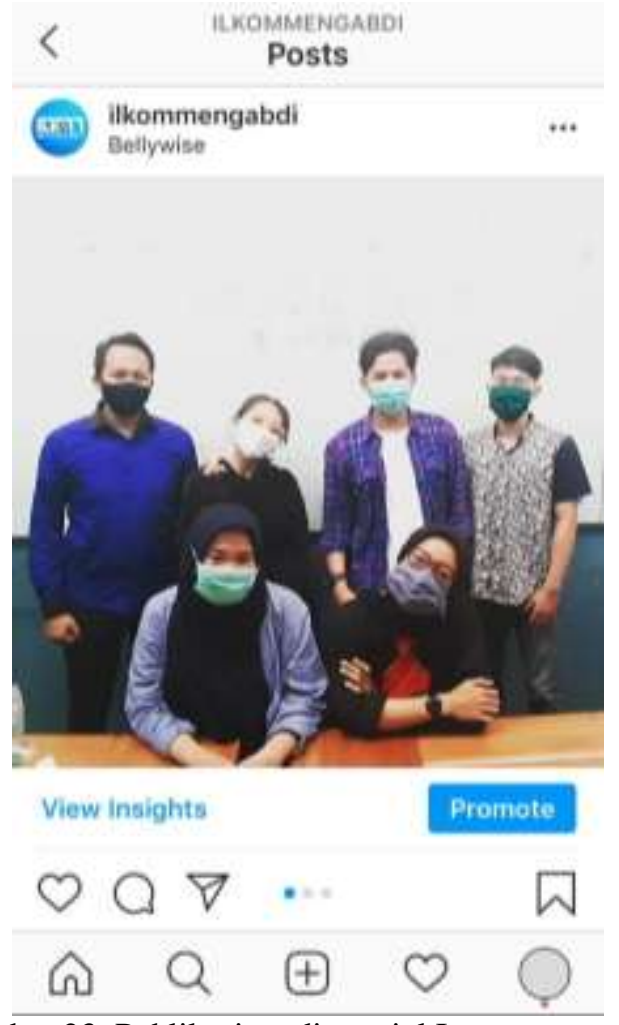

Gambar 23. Publikasi media social Instagram @ilkommengabdi

Adapun luaran nyata dari kegiatan pengabdian ini adalah penciptaan E-Katalog Kampong Tematik.

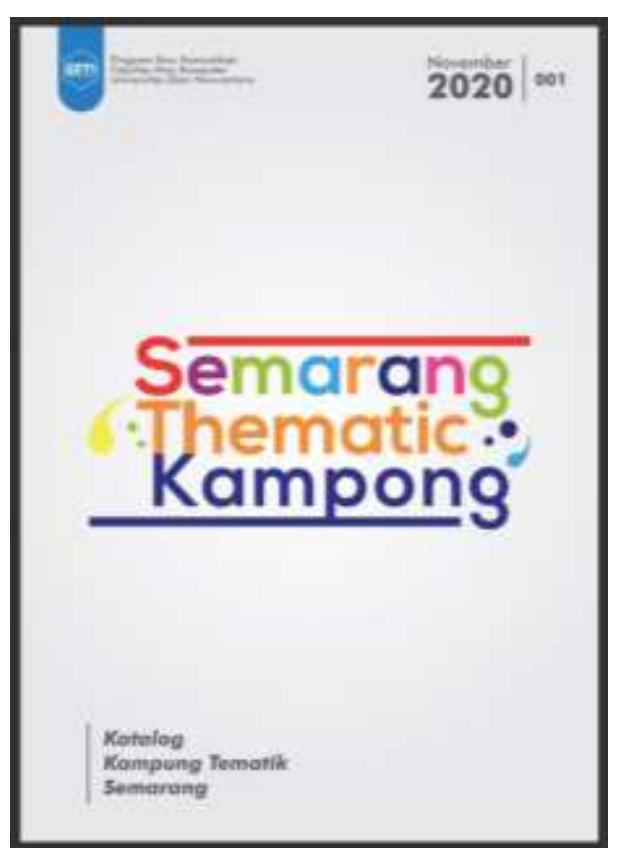

Gambar 24. Sampul E-Katalog Kampung Tematik 


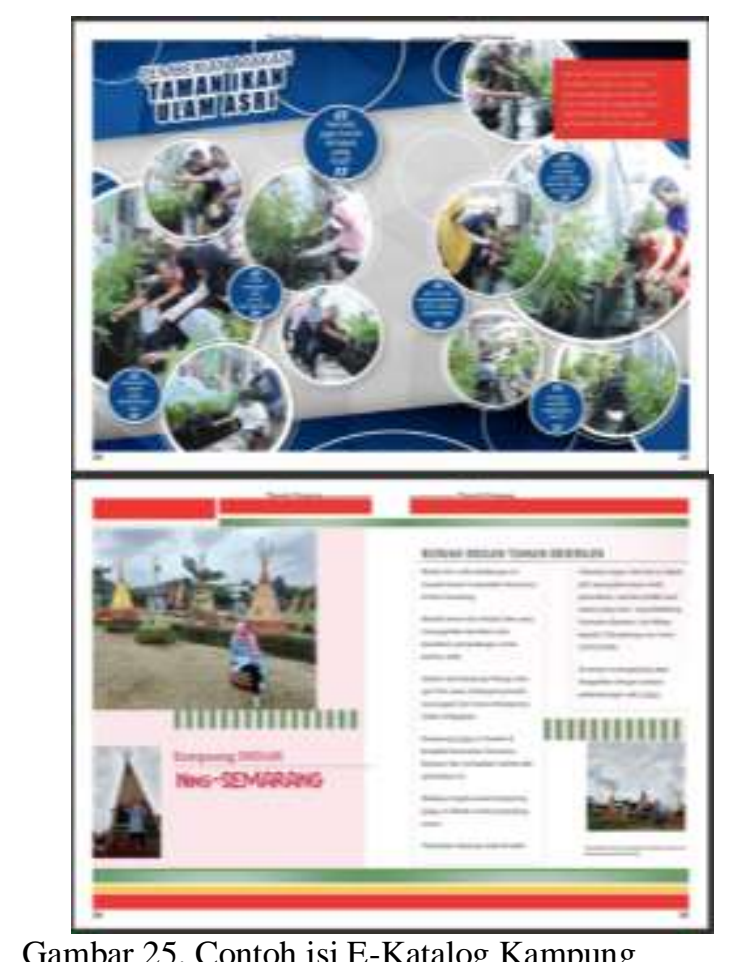

Gambar 25. Contoh isi E-Katalog Kampung Tematik

Adapun peluang dari kegiatan ini adalah adanya peran serta pemuda dan pemudi dari Karang Taruna untuk ikut berperan dalam mewujudkan keberhasilan program Kampung Tematik di Kota Semarang. di sisi lain, tantangan yang dihadapi adalah masih banyak Kampung Tematik yang dinilai belum berhasil dalam menonjolkan potensi lokalnya secara maksimal, sehingga belum dapat dipromosikan dan dipublikasikan melalui E-Katalog Kampung Tematik Kota Semarang.

Kendala yang dihadapi dalam melakukan kegiatan pemberdayaan untuk Karang Taruna ini adalah keterbatasan ruang di luar jaringan atau pertemuan fisik. Kegiatan workshop dengan pertemuan secara online dirasa kurang maksimal, selain karena keterbatasan jaringan internet, mentor dan peserta juga tidak dapat secara langsung berinteraksi dalam pembelajaran.

Keberlanjutan kegiatan ini, nantinya akan dibentuk tim inti untuk mengelola E-Katalog Kampung Tematik sehingga dapat dipublikasikan secara berkala. Adapun target ruang-ruang yang digunakan untuk mempublikasikan E-Katalog ini diantaranya website Bappeda Kota Semarang dan website Pemerintah Kota Semarang berikut dengan akun-akun sosial medianya.

\section{SIMPULAN DAN SARAN}

Pengabdian kepada masyarakat yang dilakukan melalui Workshop E-Katalog diketahui mampu meningkatkan pengetahuan, pemahaman anggota karang taruna tentang desain grafis dan copywriting untuk pengaplikasian pada E-Katalog. Hal ini ditunjukkan melalui hasil pre test dan post test.

Selain juga menumbuhkan kesadaran karang taruna untuk berperan aktif pada program kampung tematik, workshop ini juga memberikan bekal keahlian teknis dalam bidang promosi melalui desain grafis dan copywriting, yang nantinya dapat digunakan secara praktis, baik dalam berorganisasi maupun dunia kerja.

Workshop ini diharapkan mampu memberikan sumbangsih yang signifikan terhadap program kampung tematik Kota Semarang, melalui karang taruna. Karang taruna dinilai sebagai wadah generasi muda yang idealnya menjadi ujung tombak kemajuan kota, terlebih untuk program kampung tematik di Kota Semarang.

Selain itu diharapkan program-program lanjutan akan terus dilakukan. Kolaborasi dengan seluruh elemen masyarakat dinilai penting untuk mendukung program kampung tematik, untik kemajuan Kota Semarang.

\section{UCAPAN TERIMA KASIH}

Ucapan terima kasih dihaturkan kepada LPPM Universitas Dian Nuswantoro sebagai Lembaga yang menaungi pengabdian kepada masyarakat ini. Selain itu terima kasih dihaturkan pula kepada Karang Taruna dan Karang Taruna Kartini Kota Semarang sebagai mitra.

\section{DAFTAR PUSTAKA}

Betz, C. L. (2019). Generations X, Y, and Z. Journal of Pediatric Nursing, 44, A7-A8. https://doi.org/10.1016/J.PEDN.2018.12.01 3

Chaffey, D. (2016). Definitions of Digital marketing vs Internet marketing vs Online marketing. https://doi.org/21 Dec, 2016

Kotler, P. \& A. (2008). Prinsip-Prinsip Pemasaran (Edisi 12). Jakarta: Erlangga.

Marhaeni K, D. (2008). Jurnal Ilmiah Komunikasi REPRESENTASI ANAK- 
ANAK DALAM TAYANGAN IKLAN KOMERSIAL DI MEDIA, 1(1), 1-11. Retrieved from www.agbnielson.net

Philip, L. (2018). Exploring the Role of Culture on Graphic Designs. International Journal of Trend in Scientific Research and Development, Volume-2(Issue-3), 424-435. https://doi.org/10.31142/ijtsrd10857

Pujakesuma, A. (2018). Usai Kampung Tematik, Hendi Kembali Inisiasi Lomba Kampung Ekonomi Kreatif. Retrieved April
1, 2019, from https://semarang.merdeka.com/kabarsemarang/usai-kampung-tematik-hendikembali-inisiasi-lomba-kampung-ekonomikreatif-1807315.html

Riduwan, A. (2016). Pelaksanaan Kegiatan Pengabdian. EKUITAS (Jurnal Ekonomi Dan Keuangan), 3. https://doi.org/DOI: 10.24034/j25485024.y1999.v3.i2.1886 